\title{
PRIZNANJE I OVRHA NA PODRUČJU EU - uzajamno povjerenje i zaštita temeljnih ljudskih prava -
}

\author{
UDK: $341.9(4)$ \\ Izvorni znanstveni rad \\ Primljeno: 15. 12. 2016.
}

\begin{abstract}
U području slobode, sigurnosti i pravde, uzajamno povjerenje usko je povezano s uzajamnim priznanjem. Uzajamno priznanje omogućava da odluka donesena u jednoj državi članici bude priznata i ovršena u drugoj državi članici kao da je riječ o domaćoj odluci. Nema uzajamnog priznanja bez uzajamnog povjerenja. Nema uzajamnog povjerenja bez zaštite temeljnih ljudskih prava. Iako se, u primarnom pravu EU, izrijekom nigdje ne spominje, uzajamno povjerenje eksplicitno je navedeno kao okosnica brojnih akata sekundarnog prava EU. Na žalost, europski zakonodavac nije se potrudio pojasniti moguća značenja i ulogu te sintagme. Stoga se u ovom radu osvrćemo na razvoj ideje uzajamnog povjerenja, potom na ulogu uzajamnog povjerenja kao podloge za priznanje i ovrhu u kontekstu unutarnjeg tržišta te područja slobode, sigurnosti i pravde, i, za kraj, u praksi Suda EU i Europskog suda za ljudska prava.
\end{abstract}

Ključne riječi: Europska unija, priznanje i ovrha, uzajamno povjerenje, temeljna ljudska prava

\section{UVOD}

U vrijeme osnivanja Europske ekonomske zajednice, temeljni cilj novoosnovane regionalne organizacije bio je stvaranje zajedničkog tržišta za slobodnu trgovinu, kasnije nazvanog ,unutarnje tržište“. Iz perspektive dotadašnjeg pravnog ustroja i nepodijeljenih nacionalnih suvereniteta, i sama ekonomska integracija činila se (pravno-politički) teško dostižnim ciljem. Stoga ne čudi što su i ključni programski dokumenti tom pitanju pristupali s oprezom. Tako je i u Šumanovoj deklaraciji ${ }^{1}$ opetovano ponavljana teza da je ekonomsku integraciju potrebno ostvarivati postupno, prilagođavajući postojeću pravno-političku arhitekturu s obzirom na krajnji cilj. Iako „europska“ pravosudna politika u tom trenutku zasigurno nije bila prioritet, Ugovor o osnivanju Europske ekonomske zajednice ${ }^{2}$ postavio je temelj budućeg europskog procesnog prava. Naime, člankom $220 .{ }^{3}$ predviđao je mogućnost

Schuman Declaration of 9 May 1950 - „Europe will not be made all at once, or according to a single plan. It will be built through concrete achievements which first create a de facto solidarity." Dostupno na: http://europa.eu/about-eu/basic-information/symbols/europe-day/schuman-declaration.

2 Treaty establishing the European Economic Community, potpisan 25. ožujka 1957. u Rimu i na snazi od 1. siječnja 1958.

3 Poslije, čl. 293. Ugovora o EZ. 
da države članice tadašnje EEZ stupe u pregovore o donošenju instrumenta kojim bi se osiguralo uzajamno priznanje i ovrha odluka donesenih u državama članicama. Prvi takav instrument jest Briselska konvencija iz 1968. godine, ${ }^{4}$ koja je poslije prerasla u Uredbu Brisel I, ${ }^{5}$ revidiranu Uredbom Brisel I bis. ${ }^{6}$ Nakon nekoliko godina, Ugovorom iz Amsterdama, ${ }^{7}$ ostvareni su preduvjeti i za stvaranje Područja slobode, sigurnosti i pravde ${ }^{8}$ kao područja bez unutarnjih granica. Time je i konačno potvrđeno da Europska unija više nije isključivo posvećena ekonomskim ciljevima vezanima uz uspostavu jedinstvenog tržišta. ${ }^{9}$ Naime, europska integracija u svim je trima područjima politike (kaznenom, građanskom i imigraciji i azilu) ubrzala ne samo pokušaje harmonizacije nacionalnoga prava, nego i napore na pojačanju međudržavne suradnje. Različitim aktima acquisa uspostavljeni su brojni sustavi suradnje, s ultimativnim ciljem automatske međudržavne suradnje, između ostaloga, automatskog priznanja i ovrhe.

Načelo uzajamnog priznanja prihvaćeno je kao najprikladniji način za nadilaženje opozicije od strane pojedinih država članica EU harmonizaciji određenih aspekata njihovih nacionalnih prava. Godinu dana poslije, na sastanku u Tampereu, ${ }^{10}$ Europsko vijeće odredilo je tri prioriteta ${ }^{11}$ za djelovanje u okviru pravosudne suradnje između država članica, s načelom uzajamnog priznanja u središnjoj ulozi (,kamen temeljac sudske suradnje u građanskim i kaznenim predmetima unutar Unije $\left.{ }^{6}\right) .{ }^{12}$ Kako uspješna primjena navedenog načela (s obzirom na to da u kontekstu područja slobode, sigurnosti i pravde zapravo limitira individualne slobode) $)^{13}$

4 Brussels Convention on jurisdiction and the enforcement of judgments in civil and commercial matters, 1968., S1. 1. L 299/32, 1972.

5 Uredba Vijeća (EZ) br. 44/2001 od 22. prosinca 2000. o nadležnosti, priznavanju i izvršenju sudskih odluka u građanskim i trgovačkim stvarima, Sl. 1. EZ L 12/1, od 16. I. 2001.

6 Uredba (EU) br. 1215/2012 Europskog parlamenta i Vijeća od 12. prosinca 2012. o nadležnosti, priznavanju i izvršenju sudskih odluka u građanskim i trgovačkim stvarima, S1. 1. EU L 351, od 21. XII. 2012.

Treaty of Amsterdam amending the Treaty of the European Union, the Treaties establishing the European Communities and certain related acts, potpisan 2. listopada 1997., na snazi od 1. svibnja 1999.

8 Glava IV. Ugovora o EZ, čl. 61-68.

9 Lenaerts, K.: „The Principle of Mutual Recognition in the Area of Freedom“, Security and Justice, dostupno na: https://www.law.ox.ac.uk/sites/files/oxlaw/the_principle_of_mutual_recognition_in_the area_of_freedom_judgelenaerts.pdf, str. 1 .

10 Tampere European Council, 15.-16. X. 1999., Presidency Conclusions, http://www.europarl. eu.int/summits/tam_en.html, preuzeto 26. VIII. 2004. Usporedi i: http://dgei.mir.es/es/general/Tampere European_Council_en.pdf, preuzeto 26. VIII. 2004.

11 Bolji pristup pravosuđu, uzajamno priznanje sudskih odluka i veću usklađenost u segmentu procesnoga prava.

12 (Tampere) Presidency Conclusions, toč. 33. Osobito, „u građanskim predmetima, Europsko Vijeće poziva Komisiju da napravi prijedlog za daljnju redukciju međumjera (intermediate measures) koje se još uvijek postavljaju kao uvjet priznanja i ovrhe odluke ili presude u državi u kojoj se priznanje traži. ... Takve bi odluke bile automatski priznate u čitavoj Uniji bez ikakvih međupostupaka ili razloga za odbijanje ovrhe. Ovo bi moglo biti popraćeno uspostavljanjem minimalnih standarda o pojedinim aspektima građanskog postupovnog prava."Ibid., toč. 34 .

13 Za razliku od njegove uloge u kontekstu unutarnjeg tržišta, gdje ima za cilj oslobađanje ekonomskih operatera od dvostrukog tereta uvjetovanog dvostrukim setom različitih standarda. Tako: Barnard, C.: The Four Freedoms, 4th ed., Oxford University Press, Oxford, 2013., str. 93. et seq. Međutim, uspješna 
implicira postojanje uzajamnog povjerenja (da sve države članice EU respektiraju i u potpunosti štite temeljna prava), ${ }^{14} \quad$ uzajamno povjerenje uskoro je postalo jedna od temeljnih poštapalica u odnosu na budućnost europskog međunarodnog privatnog prava. ${ }^{15}$

$\mathrm{Na}$ žalost, europski zakonodavac nije sebi dao truda i pojasnio moguća značenja i uloge te sveprisutne i prilično „maglovite“ sintagme. Nedostatak konceptualizacije pojma uzajamnog povjerenja onemogućio je sustavnu diskusiju o značenju i granicama te ideje, međutim, nije spriječio Uniju da i nadalje u različite regulatorne instrumente ,ugrađuje“ uzajamno povjerenje kao raison d'être Europske unije. ${ }^{16}$ Stoga ćemo daljnji tekst najprije posvetiti povijesnom ekskursu u ideju uzajamnog povjerenja. Potom ćemo se osvrnuti na ulogu uzajamnog povjerenja kao podloge za priznanje i ovrhu stranih sudskih odluka u kontekstu unutarnjeg tržišta te područja slobode, sigurnosti i pravde; te u praksi Suda EU i Europskog suda za ljudska prava (dalje: ESLJP).

\section{KRATKI POVIJESNI EKSKURS U IDEJU UZAJAMNOG POVJERENJA}

U svim ranim modernim shemama sociopolitičkog poretka od 60-ih godina prošlog stoljeća naovamo, koncepcija uzajamnog povjerenja predstavlja središnju ideju. ${ }^{17}$ Generalno govoreći, povijest ideje uzajamnog povjerenja ukazuje na dvije temeljne razvojne značajke: prvu, sporu promjenu u pogledu odgovora na pitanje kome vjerovati, i drugu, činjenicu da je povijest povjerenja zapravo povijest obuzdavanja nepovjerenja. ${ }^{18}$ Pogled na prvu značajku pokazuje dugu povijest isključivog vjerovanja u Boga i božansku pravdu i odmazdu, no s vremenom su

primjena načela uzajamnog priznanja u kontekstu unutarnjeg tržišta traži postizanje ravnoteže između ,javnog interesa“ i ,individualne slobode“ te je, stoga, podvrgnuta i određenim ograničenjima. Vidi: Möstl, M.: „Preconditions and Limits of Mutual Recognition“, Common Market Law Review, Vol. 47, 2010., str. 405.; Janssens, C.: The Principle of Mutual Recognition in EU Law, Oxford University Press, Oxford, 2013.

14 Mitsilegas, V.: The Limits of Mutual Trust in Europe's Area of Freedom, Security and Justice: From Automatic Inter-State Cooperation to the Slow Emergence of the Individual, Yearbook of European Law, Vol. 31, No. 1, 2012., str. 319. Vidi i: Bay Larsen, L.: „Some Reflactions on Mutual recognition in the Area of Freedom", Security and Justice, u: Cardonnel, P./Rosas, A./Wahl, N (ur.): Constitutionalising the EU Judicial System: Essays in Honour of Pernilla Lindh, Hart Publishing, Oxford, 2012., str. 140.

15 Weller, M.: „Mutual trust: in search of the future of European Union private international law“, Journal of Private Innternational Law, Vol. 11, No. 1, 2015., str. 64.

16 Gerard, D./Brouwer, E.: „Mapping Mutual Trust - an Introduction“, u: Gerard, D./Brouwer, E. (ur.): Mapping Mutual Trust: Understanding the Framing the Role of Mutual Trust in EU Law, EUI Working Paper, MWP, 2016/14, str. 1.

17 Fillafer, F. L.: „Mutual Trust in the History of Ideas“, u: Gerard, D./Brouwer, E. (ur.): Mapping Mutual Trust: Understanding the Framing the Role of Mutual Trust in EU Law, EUI Working Paper, MWP, 2016/14, str. 5.

18 Tako: Hobbes, T.: De Cive, Paris, 1642. i Tricaud, F.: „'Homo homini Deus', 'Homo homini Lupus': Recherche des Sources de deux Formules de Hobbes“", u: Koselleck, R./Schnur, R.: HobbesForcshungen, Berlin, 1969., str. 61-70. Citirano prema Gerard/Brouwer, op. cit., bilj. 16, str. 6. 
međuljudski odnosi povjerenja inicirali korekciju supremacije božanskog dizajna u korist socijalne prakse, kako u teologiji tako i u pravu. Pogled na drugu značajku pokazuje da je povijest otklanjanja ili poklanjanja povjerenja vezana uz anticipaciju (crédit mutuel), tj. uz naša očekivanja od budućnosti. Kasnija povijest ideja na to nadograđuje i dvostruko značenje povjerenja (povjerenje među građanima $\mathrm{i}$ povjerenje među državama), kao načela koje upravlja međuljudskim i međunarodnim odnosima, a vezano je uz reciprocitet kao sustav socijalnih očekivanja ili bihevioralnu rutinu koja osigurava predvidljivost oblika ponašanja; što u kasnijem povijesnom razvoju postaje središnji element prirodne pravne tradicije sadržane u konceptu officia erga alios. ${ }^{19}$

I rana moderna konceptualizacija ideje uzajamnog povjerenja također manifestira dva glavna elementa - tenziju između načela volje i načela povjerenja u obveznom pravu te prirode prava kao sustava obveza ili sustava sloboda. ${ }^{20}$ Prvo se prepoznaje kao ideja o naknadi štete, tajnosti, odnosu između davatelja i korisnika jamstva, ukratko, kao uvođenje načela jednakosti i razmjernosti. Ovo drugo prepoznaje se kao opravdano očekivanje građana da će se i njihovi sugrađani pridržavati obveza koje im nameće bilo prirodno bilo pozitivno pravo. Kasnija moderna konceptualizacija u jednadžbu uvodi i antropološke i ekonomske elemente koji dodatno kompliciraju ionako nedostatno definirani koncept. Naime, neke od tih teorija ističu da je čovjekova izopačenost i instinktivna čežnja za samozadovoljenjem neizlječiva (unatoč postojanju prirodne distributivne sheme koja koordinira mnoštvom mana i može voditi predvidivom ishodu), čime ugrožavaju temelje vjerovanja u univerzalnost i nepromjenjivost morala te socijalni ugovor kao temelj političkog poretka. ${ }^{21}$ Paralelno s time, razvija se i ideja o povjerenju kao isključivo ekonomskoj kategoriji koja ima središnju ulogu na tržištu, što se u praksi pokazalo neodrživim ${ }^{22}$ i ujedno označilo njezin kraj. Pojavom Adama Smitha i Teorije moralnih osjećaja (1975.), ${ }^{23}$ uzajamno povjerenje objašnjava se kao pokušaj usklađivanja slobode članova društva da stvaraju vlastite moralne obveze i njihovih odgovornosti prema drugim članovima društva. ${ }^{24}$ Ideju povjerenja temelji na pouzdanosti i očekivanjima između pojedinaca uključenih u razborito ostvarivanje svojih ekonomskih interesa te pozitivnom socijalnom učinku (moralnom odobravanju). Za razliku od svojih prethodnika, smatra da se moral ne može svesti na niz prirodnih zakona jer ljudska vrsta ima i sposobnost biti ,nepristrani promatrač“ (tj. sudac i promatrač) i na temelju

19 Tako: Fillafer, op. cit., bilj. 17, str. 6.

20 Vidi: Nanz, K.-P.: Die Entstehung des allgemeinen Vertragsbegriffs im 16. bis 18. Jahrhundert, Munich, 1985., str. 67, 143 i Luig, K.: „Leibniz und die Prinzipien des Vertrasrechts“, u: Kerbegan, J.F./Mohnhaupt, H. (ur.): Gesellschaftliche Freiheit und vertragliche Binding in Rechtsgesichtichte und Philosophie, Frankfurt am Main, 1999., str. 75-93, 77.

21 Hundert, E.: The Enlightenment's Fable: Bernard Mandeville and the Discovery of Society, Cambridge, 2005.

22 Rezultiralo je tzv. South Sea Bubbleom (1720.), tj. bankrotom kompanije osnovane od strane britanske vlade s isključivim ciljem konsolidacije nacionalnog duga.

23 Teorija moralnih osjećaja temeljena je na društvenoj organizaciji, izgradnji identiteta, normativnih standarda te na ljudskom ponašanju u cjelini.

${ }^{24}$ Haakonsen, K. (ur.): Adam Smith, The Theory of Moral Sentiments, Cambridge, 2002., str. 399. 
vlastite svijesti razlikovati dobro od lošeg. ${ }^{25}$ Drugim riječima, povjerenje temelji na slobodi i moralu pojedinca te mudrosti i umjerenosti društvene regulacije. Da bez povjerenja kao temelja nema ni društvenog života, ističe i Comte, koji forte stavlja upravo na tu socijalnu komponentu. Po njemu, povjerenje omogućava održavanje javnog prestiža vjerovanja grupa koje vode društvo, podjelu rada te vjerovanje u mogućnost otkrivanja misterija svijeta. ${ }^{26}$ Ističe da naizgled nepredvidljivi svijet zapravo slijedi nepromjenjive, stalne uzorke slične pravilnostima koje nalazimo u pravu. Sredinom 20. stoljeća, idejom povjerenja bave se i Gehlen i Adorno, od kojih prvi vidi rješenje u institucijama koje „osiguravaju postojanje socijalnih veza u inače atomiziranom i tehnički orijentiranom društvu“, dok drugi upravo institucije smatra posljednjim čavlom u lijes uzajamnog povjerenja. ${ }^{27}$

Među recentnim autorima, odnos povjerenja i prava možda najbolje opisuje Luhmann. ${ }^{28}$ Po njemu, povjerenje je „elementarna činjenica društvenog života“, „povjerenje u vlastita očekivanja u odnosu na druge ljude“. Povjerenje je ponašanje koje omogućava planiranje mogućih alternativa u odnosu na budućnost. Iz tog aspekta, pravo i povjerenje funkcionalni su ekvivalenti, jedino je pitanje kako ih izbalansirati.

Iako se europski zakonodavac, ni eksplicitno ni implicitno, ne oslanja niti na jednu od supra navedenih ideja, ipak ih je moguće prepoznati kao više ili manje značajne u različitim kontekstima u kojima se europski zakonodavac poziva na uzajamno povjerenje. ${ }^{29}$

25 Weinstein, J. R.: Internet Encyclopedia of Philosophy, dostupno na: http://www.iep.utm.edu/ smith/

26 Heinritz-Fuchs, W.: Auguste Comte: Einführung in Leben und Werk, Wiesbaden, 1998.

27 Vidi: Fillafer, op. cit., bilj. 17, str. 9 i 10.

28 Luhmann, N.: Vertrauen, 4th ed., Frankfurt, 2000.

29 Primjerice, $u$ kontekstu jedinstvenog tržišta, europskog procesnog prava u širem smislu, priznanja i ovrhe, litispendencije, kolizijskih pravila itd. Vidi: Mitsilegas, op. cit., bilj 14, str. 319-372; Späth, P./ Blobel, F.: ,The Tale of Multilateral Trust and the European Law of Civil Procedure“, ELRev., 2000., str. 529-548; Kramer, X. E.: „Cross-Border Enforcement and the Brussels I-Bis Regulation. Towards A New Balance Between Mutual Trust And National Control over Fundamental Rights“, Netherlands International Law Review, 2006., str. 364-367; Weller, op. cit., bilj. 15, str. 75-81. 


\section{UZAJAMNO POVJERENJE KAO TEMELJ JEDINSTVENOG TRŽIŠTA}

Kao što je već ranije spomenuto, stvaranje jedinstvenog unutarnjeg tržišta inspirirano je isključivo ekonomskim faktorima, a ne idejom uzajamnog povjerenja. Nekih dvadeset godina nakon prvog pokušaja ekonomske integracije i očite nemogućnosti drugih institucija Zajednice da ostvare namjeravani cilj, ${ }^{30}$ institucionalno vodstvo preuzima Sud EU svojim odlukama u predmetima Dassonville ${ }^{31}$ and van Binsbergen. ${ }^{32}$ Nedugo potom, slijede i prve odluke Suda utemeljene na ideji uzajamnog priznanja utemeljenog na uzajamnom povjerenju. Radi se o odlukama Cassis de Dijon, ${ }^{33}$ van Wesemael $^{34}$ te Säger, ${ }^{35}$ čiji se učinak, u konačnici ipak pokazao ograničenim.

Naime, ograničenja nametnuta nacionalnim zakonodavstvima Sud EU je proglasio ograničenjem slobode kretanja roba (čl. 34. UFEU-a), te ih je dozvolio samo onda kada su u skladu s načelom razmjernosti. Načelo države porijekla (country-of-origin principle $)^{36}$ nalaže svim državama članicama da priznaju ograničavajuće mjere u državi članici porijekla, osim kad je riječ o mjerama koje osiguravaju razinu zaštite ekvivalentnu razini zaštite predviđene u državi odredišta. ${ }^{37}$ Drugim riječima, nije dozvoljeno bezrezervno nepovjerenje, ali ne traži se niti bezrezervno povjerenje. Ovakvo „kvalificirano“ uzajamno povjerenje pokazalo se donekle ograničavajućim faktorom namjeravane integracije tržišta. ${ }^{38}$ Promatrano iz perspektive biznisa, bilo kakva ograničenja od strane nacionalnih zakonodavaca ostavljaju prostora za odbijanje uzajamnog priznanja, što za posljedicu ima i pravnu i ekonomsku nesigurnost. ${ }^{39}$ Iz perspektive nacionalnih zakonodavstava, nedostatak potpune kontrole nad proizvodima koji kolaju nacionalnim tržištem vodi ka odgovornosti za situacije na koje zapravo nemaju utjecaja te potencijalnom nezadovoljstvu domaćih

30 Menéndez; A. J.: „The Existential Crisis of the European Union“, German Law Journal, No. 14, 2013., str. 471-484.

31 Case C-8/74 Procureur du Roi v Benoit and Gustave Dassonville [1974.] ECR 00837.

32 Case C-33/74 Johannes Henricus Maria van Binsbergen v Bestuur van de Bedrijfsvereniging voor de Metaalnijverhed [1974.] ECR 01299.

33 Case C-120/78 Rewe Zentral v Bundesmonopolverwaltung für Branntwein [1979.] ECR 00649.

34 Joined cases C-110/78 and 111/78 Ministère public and,, Chambre syndicale des agents artistiques et impresarii de Belgique" ASBL v Willy van Wesemael and others [1979.] ECR 00035.

35 Case C-76/90 Manfred Säger v Dennemeyer \& Co. Ltd.[1991.] ECR I-04221.

36 Prema nekim autorima, načelo države porijekla funkcionira slično stečenim pravima. Vidi: Kuipers, J.-J.: ,Cartesio and Grunkin-Paul: Mutual Recognition as a vested Rights Theory Based on Party Autonomy in Private Law", European Journal of Legal Studies, Vol. 2, Issue 2, 2009., str. 66-114.

37 Kao što je naveo Sud EU u predmetu C-187/01 Hüseyn Gözütok i C-385/01 Klaus Brügge [2003.] ECR I-01345, uzajamno povjerenje ne zahtijeva jednaku zaštitu već jednakovrijednu zaštitu, čak i ako bi se ishod razlikovao u odnosnim državama članicama.

38 Snell, J.: „The Single Market: Does Mutual Trust Suffice?“, u: Gerard, D./Brouwer, E. (ur.): Mapping Mutual Trust: Understanding the Framing the Role of Mutual Trust in EU Law, EUI Working Paper, MWP, 2016/14, str. 11.

39 Pelkmans, J.: „Mutual recognition in goods: on promisses and disillusions“, Journal of European Public Policy, Vol. 14, 2007., str. 699. 
tržišnih natjecatelja. ${ }^{40}$ Konačno, iz perspektive organiziranih interesnih grupa, ideja uzajamnog povjerenja i na njoj utemeljeno uzajamno priznanje zapravo predstavlja prijetnju jer omogućava regulatorno natjecanje koje ugrožava interese takvih grupa ${ }^{41}$ Stoga ne čude sve glasnija razmišljanja da je temeljni preduvjet potpune ekonomske integracije ili potpuno uzajamno povjerenje ili, u nemogućnosti njegova ostvarivanja, povratak na sustav koji je više utemeljen na harmonizaciji, a manje na uzajamnom povjerenju. ${ }^{42}$

Ipak, pitanje je treba li, u kontekstu unutarnjeg tržišta, načelo uzajamnog priznanja utemeljiti na potpunom uzajamnom povjerenju. ${ }^{43}$ Uzajamno priznanje, uz ograničenja utemeljena isključivo na načelu razmjernosti, zajedno s drugim upravljačkim tehnikama omogućava postizanje osjetljive ravnoteže potrebne za opstanak unutarnjeg tržišta. ${ }^{44}$ Osobito u kontekstu namjeravanih daljnjih proširenja Europske unije. ${ }^{45}$ To tim više što su i dosadašnja događanja na unutarnjem tržištu zorno pokazala da razlika u ekonomskoj razvijenosti među državama članicama sama po sebi kumulira nesigurnost. ${ }^{46}$ Stoga ne čudi da je dosadašnji razvoj događaja umjesto uzajamnog povjerenja u nacionalna tijela i zakonodavstvo drugih država članica neočekivano skrenuo ka liderstvu europskih tijela i zakonodavstva. ${ }^{47}$

\section{UZAJAMNO POVJERENJE KAO NAČELO MEĐUNARODNOG PRIVATNOG PRAVA}

Prema odredbi čl. 2. Ugovora o EU, ${ }^{48}$ a također i čl. 2. Ugovora o funkcioniranju EU, ${ }^{49}$ Europska unija utemeljena je na ,vrijednostima kao što su poštovanje ljudskog dostojanstva, slobode, demokracije, jednakosti, vladavine prava i poštovanja ljudskih prava“ i te vrijednosti su ,zajedničke državama članicama u društvu u

40 Snell, op. cit., bilj. 38, str. 12.

41 Ibidem, str. 13.

42 Ibidem, str. 14.

43 Pro te ideje: Snell, op. cit., bilj 38, str. 113 i 14. Contra navedene ideje vidi: Storskrubb, E.: „Mutual Trust and the Limits of Abolishing Exequatur in Civil Justice“, u: Gerard, D./Brouwer, E. (ur.): Mapping Mutual Trust: Understanding the Framing the Role of Mutual Trust in EU Law, EUI Working Paper, MWP, 2016/14, str. 19.

44 Nicolaïdis, K.: „,Trusting the poles? Constructing Europe through mutual recognition“, Journal of European Public Policy, Vol. 14, No. 5, 2007., str. 683-686.

45 Delhey, J.: ,Do enlargements make the European Union less cohesive? An analisys of mutual trust between EU nationalities“, Journal of Common Market Studies, Vol. 45, Issue. 2, str. 253-279.

46 Vidi: Enderlein, H. et al.: „Completing the Euro: A Road Map towards Fiscal Union in Europe Report of the 'Tommaso Padoa-Schioppa Group'“, Notre Europe, Paris, 2012.

47 Vidi: Alexander, K.: „European banking union: a legal and institutional analisys of the single supervisory mechanism and the single resolution mechanism“, European Law Review, Vol. 40, No. 2, 2015., str. 154-187.

48 Vidi bilj. 7.

49 Stupio na snagu 1. prosinca 2009. Pročišćenu inačicu vidi u S1. L. EU C 203, 2016. 
kojem prevladavaju pluralizam, ne-diskriminacija, tolerancija, pravda, solidarnost i jednakost između muškaraca i žena“.

$\mathrm{Za}$ razliku od primarnoga prava EU, koje ga izrijekom nigdje ne spominje, načelo uzajamnog povjerenja eksplicitno je navedeno kao okosnica brojnih akata europskog međunarodnog privatnog prava. ${ }^{50}$ Načelo uzajamnog povjerenja dio je europskog zakonodavstva već desetljećima i vodeća ideja procesa prilagodbe prava u smjeru slobodnog kretanja odluka teritorijem EU. ${ }^{51}$ Kao regulatorna metoda i „kamen temeljac“ europskog procesnog prava predstavljeno je još 1999. godine u Tampereu, u vidu „Programa za implementaciju načela uzajamnog priznanja“. Time je učinjen prvi korak, međutim, sam proces ukidanja egzekvature (kao glavni pokazatelj uzajamnog povjerenja) još uvijek je moguće okarakterizirati kao „work in progress".

Naime, do 2004. godine, automatsko priznanje i ovrhu predviđala je tek jedna uredba, Uredba Brisel II bis, i to isključivo u pogledu odluka koje se odnose na pravo na susrete i druženje i odluka kojima se traži povratak djeteta. ${ }^{52}$ Tako se, prema odredbama čl. 41., ovršna odluka o pravu na susrete i druženje priznaje i ovršava u drugoj državi članici bez potrebe za proglašenjem ovršnosti i bez mogućnosti protivljenja njezinu priznanju, pod uvjetom da je uz nju priložena potvrda o ovršnosti odluke izdana ${ }^{53}$ od strane nadležnog suda u državi članici porijekla odluke. ${ }^{54}$ Prema odredbi st. 1. čl. 42., i ovršna odluka donesena u državi članici kojom se traži povratak djeteta priznaje se i ovršava u drugoj državi članici bez potrebe za proglašenjem ovršnosti i bez mogućnosti protivljenja njezinu priznanju, pod uvjetom da je uz nju priložena potvrda o ovršnosti naloga ${ }^{55}$ izdana od strane nadležnog suda u državi članici porijekla odluke. ${ }^{56}$ Sve ostale vrste odluka iz polja primjene navedene Uredbe i dalje podliježu postupku egzekvature.

50 Više o tome vidi u: Moraru, M.: ,'Mutual trust' from the Perspective of National Courts, A Ttest in Creative Legal Thinking“, u: Gerard, D./Brouwer, E. (ur.): Mapping Mutual Trust: Understanding the Framing the Role of Mutual Trust in EU Law, EUI Working Paper, MWP, 2016/14, str. 37.

51 Vidi: Župan, M.: „Europski obiteljski prekogranični postupci“, u: Ljubanović, B./Tunjica, P./ Poretti, P./Vuletić, I./Župan, M.: Procesno-pravni aspekti prava EU, Pravni fakultet Sveučilišta u Osijeku, Osijek, 2016., str. 126. i Grajdura, W.: Free circulation of judgments, dostupno na: https://www.era-comm. eu/Visegrad/kiosk/pdf/speakers_contributions/116DT34_Grajdura.pdf, str. 1.

52 Međutim, tzv. brzi postupak priznanja (fast track) ne sprečava nositelja roditeljske odgovornosti da predloži i dobije priznanje i proglašenje ovršnosti navedene odluke, u skladu s odredbama BU II bis (čl. 40. st. 2.).

53 Na standardiziranom obrascu iz Priloga III. Uredbe Brisel II bis. Potvrda se izdaje samo ako su ispunjeni uvjeti, propisani Uredbom, kojima se štiti pravo na obranu te pravo stranaka da budu saslušane.

54 Čak i ako nacionalno pravo ne predviđa ipso iure ovršnost odluka o pravu na susrete i druženje, sud države članice porijekla odluke može je proglasiti ovršnom, bez obzira na izjavljen pravni lijek (čl. 41. st. 1. reč. 2.).

55 I u ovom slučaju izdavanje navedene potvrde uvjetovano je ispunjenjem uvjeta propisanih Uredbom, s time da treba voditi računa da se uvjeti djelomično razlikuju od uvjeta propisanih za izdavanje potvrde uz odluku o pravu na susrete i druženje.

56 Čak i ako nacionalno pravo ne predviđa ipso iure ovršnost odluka kojima se traži povratak djeteta, sud države porijekla odluke može je proglasiti ovršnom bez obzira na izjavljen pravni lijek (čl. 42 . st. 1. reč. 2.). 
Stoga ne čudi što je Haškim programom, ${ }^{57}$ usvojenim 2004. godine, uklanjanje zapreka uzajamnom priznanju i dalje u vrhu prioriteta. Europsko Vijeće navelo je za glavni preduvjet osnaživanja načela uzajamnog priznanja, jačanje uzajamnog povjerenja progresivnim jačanjem europske sudske kulture utemeljene na raznolikosti nacionalnih pravnih sustava i na jedinstvu kroz pravo EU. Donošenje Uredbe o europskom ovršnom naslovu, ${ }^{58}$ Uredbe o europskom platnom nalogu, ${ }^{59}$ Uredbe o europskom postupku za sporove male vrijednosti ${ }^{60}$ označilo je prvi sustavni iskorak u smjeru ukidanja egzekvature u građanskim i trgovačkim predmetima. Navedenim su Uredbama tradicionalni razlozi za odbijanje priznanja i ovrhe, uključujući i mogućnost pozivanja na javni poredak, ukinuti i zamijenjeni određenim minimalnim standardima podložnima provjeri isključivo u državi porijekla odluke. ${ }^{61}$ Razina uzajamnog povjerenja u navedenim područjima pokazala se dostatnom za jedan takav radikalan iskorak. ${ }^{62}$ Međutim, mnoga područja i dalje su ostala izuzeta od načela automatskog uzajamnog priznanja. Tako je, primjerice, Uredbom o nasljeđivanju ${ }^{63}$ te Uredbom o uzdržavanju ${ }^{64}$ i dalje predviđena obveza ispunjavanja određenih proceduralnih uvjeta ili minimalnih standarda te mogućnost priziva, ${ }^{65}$ dok neki drugi instrumenti predviđaju drugačije uvjete. ${ }^{66}$

Zbog toga je i posljednjim programskim dokumentom, tzv. Štokholmskim programom ${ }^{67}$ predviđeno daljnje ukidanje egzekvature u području pravosudne suradnje u područjima u kojima to dosad nije učinjeno, a uzimajući u obzir specifičnosti nacionalnih pravnih sustava, uključujući javni poredak i njihove tradicije u odnosnim područjima ${ }^{68}$ Krajnji je cilj politike uzajamnog priznavanja

57 The Hague Programme: Strenghtening Freedom, Sceurity and Justice in the European Union, Sl. 1. EU C 53/1, od 3. III. 2005.

58 Uredba (EZ) br. 805/2004 Europskog parlamenta i Vijeća od 21. travnja 2004. o uvođenju europskog naloga za izvršenje za nesporne tražbine, S1. 1. EZ L 143, od 30. IV. 2004.

59 Uredba (EZ) br. 1896/2006 od 12. prosinca 2006. o uvođenju postupka za europski platni nalog, S1. 1. EZ L 399, od 20. XII. 2006.

60 Uredba (EZ) br. 861/2007 Europskog parlamenta i Vijeća od 11. srpnja 2007. o uvođenju europskog postupka za sporove male vrijednosti, S1. 1. EZ L 199, od 31. VII. 2007.

61 Detaljnije vidi u: Grajdura, op. cit, bilj. 51, str. 2 i 3.; Kramer, op. cit. bilj. 29, str. 350.

62 Weller, op. cit. bilj. 15, str. 84.

63 Uredba (EU) br. 650/2012 Europskog parlamenta i Vijeća od 4. srpnja 2012. o nadležnosti, mjerodavnom pravu, priznavanju i izvršavanju odluka i prihvaćanju i izvršavanju javnih isprava $u$ nasljednim stvarima i o uspostavi Europske potvrde o nasljeđivanju, Sl. 1. EU L 201, od 27. VII. 2012.

${ }^{64}$ Uredba Vijeća (EZ) br. 4/2009 od 18. prosinca 2008. o nadležnosti, mjerodavnom pravu, priznavanju i izvršenju sudskih odluka te suradnji u stvarima koje se odnose na obvezu uzdržavanja, S1. 1. EZ L 7/1, od 10. I. 2009. Navedena Uredba predviđa dva sustava priznanja: standardni, za odluke donesene u državama članicama koje nisu ugovornice Haškog protokola iz 2007., te automatsko priznanje i ovrhu za države članice koje su ujedno i države ugovornice Haškog protokola iz 2007. godine.

65 Čl. 39-55 Uredbe o nasljeđivanju. Vidi: Linton, M.: „Abolition of Exequatur, all in the Name of Mutual Trust", u: Hess, B./Bergström, M./Storskrubb, E. (ur.), EU Civil Justice - Current issues and Future Outlook, Swedish Studies in European Law, Vol. 7, Hart Publishing, 2016.

66 Kramer, op. cit., bilj. 29, str. 349.

67 The Stockholm Programme - A open and secure Europe serving and protecting citizens, Sl. 1. EU C 115/1, od 4. V. 2010 .

68 Ibidem, str. 24. 
slobodno kretanje svih vrsta sudskih odluka u području građanskih i trgovačkih stvari među državama članicama, te njihovo automatsko priznavanje i ovrha u drugim državama članicama. Ključni je element u razvoju prava EU u tom području postupno uklanjanje svih zapreka priznavanju i ovrsi presuda među pravosudnim sustavima država članica. Sudeći po nedavno usvojenim uredbama - Uredbi o bračnoimovinskom režimu ${ }^{69}$ i Uredbi o imovinskom režimu registriranih partnera ${ }^{70}$ te Prijedlogu revidirane Uredbe Brisel II bis ${ }^{71}$ - europsko zakonodavstvo ubrzano se kreće u zadanom smjeru.

I revidiranom Uredbom Brisel I bis također je ukinuta egzekvatura za odluke u građanskim i trgovačkim predmetima. ${ }^{72}$ Interesantno je, međutim, da države članice ipak nisu bile spremne odustati od određenih zaštitnih mjera, ponajprije razloga za odbijanje priznanja. ${ }^{73}$ Naime, još 2010. godine, Komisija je predstavila Prijedlog nove Uredbe (Brisel I bis) ${ }^{74}$ kojim je ukinuta egzekvatura za (skoro) sve vrste odluka, ${ }^{75}$ međutim, ukidanje razloga za odbijanje priznanja i ovrhe strane sudske odluke, osobito mogućnosti pozivanja na javni poredak, pokazalo se iznimno kontroverznim. Niti pozivanje na uzjamno povjerenje nije uvjerilo države članice da odustanu od kontrole odluke u državi priznanja u korist prilično limitirane kontrole u državi članici porijekla. Stoga je revidiranom Uredbom Brisel I bis ukinut postupak egzekvature, ali su zadržani razlozi za odbijanje priznanja. ${ }^{76}$ Riječima Europskog parlamenta, „država članica u kojoj se vodi postupak ima pravo štititi svoje temeljne vrijednosti; stoga, isto mora biti omogućeno i državi članici u kojoj se traži priznanje i ovrha“" ${ }^{77}$

69 Uredba Vijeća (EU) 2016/1103 od 24. lipnja 2016. o provedbi pojačane suradnje u području nadležnosti, mjerodavnog prava te priznavanja i izvršenja odluka u stvarima bračnoimovinskih režima, S1. 1. EU L 183/1, od 8. VII. 2016.

70 Uredba Vijeća (EU) 2016/1104 od 24. lipnja 2016. o provedbi pojačane suradnje u području nadležnosti, mjerodavnog prava te priznavanja i izvršenja odluka u stvarima imovinskih posljedica registriranih partnerstava, S1. 1. EU L 183/30, od 8. VII. 2016.

71 Proposal for a Council Regulation on jurisdiction, the recognition and enforcement of decisions in matrimonal matters and the matters of parental responsibility, and on international child abduction (recast), COM (2016.) 114 final, od 30. lipnja 2016.

72 Vidi: Kramer, op. cit., bilj. 29, str. 367-370; Linton, op. cit., bilj. 65; Storskrubb, E.: „Civil Justice - Constitutional and Regulatory Issues Revisited“, u: Fletchher, M./Herlin-Karnell, E./Matera, C. (ur.): The EU as an Area of Freedom, Security and Justice, Routledge Research in EU Law, 2016.

73 Beaumont, P./Johnston, E.: „Can Exequatur be abolished in Brussels I whilst retaining a public policy defence?", Journal of Private International Law, Vol. 6, No 2, August 2010, str. 247-279.

74 Proposal for a Regulation of the European Parliament annd of the Council on the jurisdiction and the recognition and enfrcement of judgments in civil and commercial matters (Recast), COM (2010.) 748 final.

75 Vidi čl. 37. st. 3. Prijedloga Uredbe Brisel I bis.

76 Vidi čl. Uredbe Brisel I bis.

77 Prema: Storskrubb, op. cit., bilj. 43, str. 18. 


\section{NAČELO UZAJAMNOG POVJERENJA U KONTEKSTU PRIZNANJA I OVRHE U PRAKSI SUDA EU}

Načelo uzajamnog povjerenja u jurisprudenciji Suda EU oduvijek je isticano kao fundamentalno načelo prava EU s obzirom na to da „omogućuje stvaranje i održavanje područja bez unutarnjih granica“ ${ }^{78}$ Tako je još 1993. , u predmetu Sonntag v. Waidmann ${ }^{79}$ nezavisni odvjetnik Darmon u svojem Mišljenju naveo da je ,načelo uzajamnog priznanja sudskih odluka utemeljeno na uzajamnom povjerenju država članica u njihove pravne sustave i njihove institucije“. ${ }^{80} \mathrm{Na}$ istom tragu utemeljeno je i Mišljenje nezavisnog odvjetnika Légera u predmetu Owusu v. N.B. Jackson, ${ }^{81}$ gdje navodi da je pojednostavljeni mehanizam priznavanja i ovrhe utemeljen Briselskom konvencijom iz 1968. godine, preuzet Uredbom Brisel I, osmišljen za potrebe priznanja i ovrhe ,u specifičnom kontekstu koji karakterizira uzajamno povjerenje između država članica Zajednice u pogledu njihovih pravnih sustava i sudskih institucija“ ". ${ }^{82}$ Navedeni pristup dodatno je osnažen Uredbom Brisel I bis, ${ }^{83}$ koja ukidanje egzekvature izrijekom vezuje uz uzajamno povjerenje. ${ }^{84}$ Tako se u recitalu 26 navedene Uredbe navodi da ,uzajamno povjerenje u sudovanje u Uniji opravdava načelo da se sudske odluke donesene u jednoj državi članici priznaju u svim državama članicama bez potrebe za provođenjem posebnog postupka ... potrebno je sudsku odluku donesenu pred sudom države članice smatrati kao da je donesena pred sudom zamoljene države članice.“

Pitanjem uzajamnog povjerenja u kontekstu priznanja i ovrhe, Sud EU bavio se $\mathrm{i}$ u odnosu na neke druge uredbe. Tako je, primjerice, u predmetu Rinau, ${ }^{85}$ vezanom uz interpretaciju Uredbe Brisel II bis, ${ }^{86}$ Sud EU istaknuo da je Uredba utemeljena na ideji da ,priznanje i ovrha odluke donesene u drugoj državi članici mora biti

78 Opinion 2/13, para. 191.

79 Case C-172/91 Volker Sonntag v Hans Waidmann, Elisabeth Waidmann and Stefan Waidmann [1993.] ECR I-1963.

80 Case C-172/92, Opinion of Advocate General Darmon, para. 71-72.

81 Case C-281/02 Andrew Owusu v. N.B. Jackson, trading as ,,Villa Holidays Bal-Inn Villas “, and Others [2005.] ECR I-1383.

82 Case C-281/02, Opinion of Advocate General Léger, para. 144. Vidi i: Whytock, C.: „Faith and Scepticism in Private Interntional Law: Trust, Governance, Politics, and Foreign Judgments", European Law Review, No. 3, 2014., str. 118 i 119.

83 Vidi bilj. 6.

84 Postoji cijeli niz drugih odluka Suda EU u kojima se Sud osvrtao na ulogu i značaj uzajamnog povjerenja (vidi: Case C-116/02 Erich Gasser GmbH v Misat Srl. [2003.] ECR I-14693; Case C-159/02 Turner v Grovit [2004.] ECR I-3565; Case C-185/07 Allianz SpA et al v West Tankers Inc [2009.] ECR I-663; Case C-456/11 Ghotaer Versicherung et al. V Samskip GmbH, ECLI:EU:C2012:719, par. 32 et seq.; Case C-452/12 Nipponkoa Insurance Co. (Europe) Ltd v Interzuid Transport BV, ECLI:EU:C:2013:858, par. 36.), ali samo neke se odnose na načelo uzajamnog povjerenja u kontekstu priznanja i ovrhe (vidi: Case C-157/12 Salzgitter Mannesmann Handel GmbH v SC Laminorul SA, ECLI:EU:C:2013:597, par. 40.; Case C-619/10 Trade Agency Ltd v Seramico Investments Ltd, ECLI:EU:C:2012:531).

85 Case C-195/08 PPU Inga Rinau [2008.] ECR I-05271.

${ }^{86}$ Uredba Vijeća (EZ) br. 2201/2003 od 27. studenoga 2003. o nadležnosti, priznavanju i izvršenju sudskih odluka u bračnim sporovima i u stvarima povezanima s roditeljskom odgovornošću, kojom se stavlja izvan snage Uredba (EZ) br. 1347/2000, S1. 1. EZ L 338, od 23. XII. 2003. 
utemeljeno na načelu uzajamnog povjerenja te da razlozi za odbijanje priznanja moraju biti svedeni na minimum“" ${ }^{87}$ Međutim, u predmetu Zarraga ${ }^{88}$ vezanom iz interpretaciju iste Uredbe, potvrdio je apsolutnu primjenu načela uzajamnog priznanja unatoč očitoj odsutnosti uzajamnog povjerenja u usklađenost pravnog sustava države porijekla odluke s temeljnim ljudskim pravima. U predmetu N.S. ${ }^{89}$ vezanom uz primjenu Uredbe Dublin II, ${ }^{90}$ Sud EU zauzeo je nešto blaži pristup. Naveo je da je „raison d'être“ Europske unije i stvaranje područja slobode, sigurnosti i pravde utemeljeno na uzajamnom povjerenju i oborivoj presumpciji uzajamnog povjerenja, tj. udovoljavanja od strane drugih država članica pravu EU i, osobito, temeljnim pravima“". ${ }^{91}$

Prema nekim doktrinarnim mišljenjima, uzajamno povjerenje je konstitucionalni aksiom koji ima za cilj inspirirati zakonodavne akcije na europskom planu, ali ne postavlja ovršne standarde. ${ }^{92}$ Nasuprot tome, Mišljenje 2/13 Suda EU, ${ }^{93}$ vezano uz mogućnost pristupanja Europske unije kao regionalne organizacije Europskoj konvenciji o temeljnim ljudskim pravima, navodi na ponešto drugačiji zaključak. Naime, navedeno Mišljenje nedvojbeno potvrđuje da je načelo uzajamnog povjerenja konstitucionalno načelo, te kao takvo prožima cjelokupno područje slobode, sigurnosti i pravde..$^{94}$ Tako navodi da „načelo uzajamnog povjerenja zahtijeva da, osobito u odnosu na područje slobode, sigurnosti i pravde, svaka država članica, osim u iznimnim okolnostima, podrazumijeva da druge države članice poštuju pravo EU i osobito temeljna prava priznata pravom EU “. ${ }^{95}$ Ovakvom definicijom zapravo potvrđuje presumpciju poštovanja temeljnih prava od strane država članica. Međutim, odbija ideju da je riječ o načelu koje ne postavlja nikakve ovršne standarde. To stoga što navedena presumpcija državama članicama nameće dvije negativne obveze. Tako države članice „,ne smiju tražiti višu razinu zaštite temeljnih prava od strane druge države članice od one koju nameće pravo EU“", ${ }^{96}$ a također su, „osim u iznimnim okolnostima“, „obvezne suzdržati se od provjere je li odnosna država članica u konkretnom slučaju uistinu i poštovala temeljna prava

87 Case C-195/08 PPU Inga Rinau, para. 50. Odluke Suda EU.

88 Case C-491/10 PPU Joseba Andoni Aguirre Zarraga v Simone Pelz [2010.] ECR I-14247, par. 49.

89 Case C-411/10 N.S. v Secretary of State for the Home Departent i C-493/10 M. E. and Others v Refugee Applications Commissioner and Minister for Justice, Equality and Law Reform [2011.] ECR I-13905.

90 Uredba Vijeća (EZ) br. 343/2003 od 18. veljače 2003. o utvrđivanju kriterija i mehanizama za određivanje države članice odgovorne za razmatranje zahtjeva za azil koji je u jednoj od država članica podnio državljanin treće zemlje, Sl. 1. EZ L 50, od 25. II. 2003. Uredba Dublin II naknadno je zamijenjena Uredbom Dublin III (Uredba (EU) br. 604/2013, Sl. L. EU L 180) koja je još uvijek na snazi u državama članicama, iako s upitnim uspjehom.

91 Paragraf 83. Odluke Suda EU u navedenom predmetu.

92 Herlin-Karnell, E.: „Constitutional Principles in the EU Area of Freedom, Security and Justice“, u: Acosta, D./Murphy, C. (ur.), EU Security and Justice Law, Hart Publishing, Oxford, 2014., str. 36.

93 Opinion 2/13, EU:C:2014:2454.

94 Lenaerts, op. cit., bilj. 9, str. 6.

95 Opinion 2/13, para. 191.

96 Opinion 2/13, para. 192. 
zajamčena pravom EU“. ${ }^{97} \mathrm{U}$ takvom kontekstu nije moguće izbjeći pitanje u kojoj mjeri novi režim osigurava ravnotežu između uzajamnog povjerenja, s jedne strane, i potrebe ili želje za kontrolom i garancijom temeljnih ljudskih prava, s druge strane.

\section{PRIZNANJE I OVRHA U PRAKSI SUDA ZA LJUDSKA PRAVA}

Ne tako davno, čak je i Europski sud za ljudska prava ustvrdio da su temeljni instrumenti prava EU utemeljeni na načelu uzajamnog povjerenja (,sur le principe de 'confiance réciproque dans la justice' au sein de l'Union" ${ }^{\text {") }} .{ }^{98} \mathrm{~Pa}$ ipak, pred navedenim sudom je sve više predmeta u kojima se propituje domašaj navedenog načela i njegova uloga u kontekstu priznanja i ovrhe.

Pokazalo se da se najveći sukobi između načela uzajamnog povjerenja i prava na pravično suđenje javljaju upravo u onim područjima pravosudne suradnje $u$ kojima je isključena supsidijarna kontrola javnog poretka u državi priznanja i ovrhe, kao što su odluke o povratku djeteta i pravu na susrete i druženje, utemeljene na odredbama Uredbe Brisel II bis. Tako je u predmetu Šneersone and Kampanella $v$ Italy, ${ }^{99}$ ESLJP odlučivao o povredi prava na privatni život ${ }^{100}$ te povredi prava na pravično suđenje. ${ }^{101}$ Pitanje uzajamnog povjerenja postavljeno je u kontekstu dijametralno suprotnih odluka donesenih od strane talijanskog i latvijskog suda. Sud je odgovorio da dijametralno suprotne odluke ne predstavljaju povredu načela uzajamnog povjerenja, ali je utvrdio neke druge povrede Konvencije. ${ }^{102}$ Nažalost, pitanje je li latvijski sud bio dužan priznati i ovršiti odluku talijanskog suda o povratku djeteta unatoč povredi temeljnih ljudskih prava od strane suda porijekla odluke, ili je pak imao mogućnost ili čak dužnost odbiti priznanje ili ovrhu, nije niti postavljeno.

Šteta je tim veća jer je, otprilike u isto vrijeme, Sud EU u predmetu Aguirre Zarraga ${ }^{103}$ potvrdio ranije iskazani stav ${ }^{104}$ da pretpostavka uzajamnog povjerenja funkcionira kao neoboriva presumpcija, čak i u slučaju povrede temeljnih ljudskih prava. ${ }^{105}$ Tako sud države članice u kojoj je zatraženo priznanje i ovrha nema druge mogućnosti osim priznati odluku popraćenu potvrdom kojom se potvrđuje njezina

97 Ibidem.

98 ESLJP, predmet br. 1702/07, Avotinš v Latvia, Odluka od 25. veljače 2014., par. 49.

99 Predmet br. 14737/09, Šneersone and Kampanella v Italy, Odluka od 12. srpnja 2011.

100 Čl. 8. Europske konvencije za zaštitu ljudskih prava i temeljnih sloboda.

101 Čl. 6. Europske konvencije za zaštitu ljudskih prava i temeljnih sloboda.

102 Potvrdio je postojanje povrede i čl. 6. i čl. 8., utemeljene na nedovoljnoj obrazloženosti odluke te nedovoljnom uvažavanju podnesaka.

103 Case C-491/10 PPU Joseba Andoni Aguirre Zarraga v Simone Pelz [2010.] ECR I-14247, par. 49.

104 Vidi: case C-211/10 PPU Doris Povse v Mauro Alpago [2010.] ECR I-06672, par. 70. (,,a judgment thus certified is automatically enforceable, there being no possibility of opposing its recognition").

105 Weller, op. cit., bilj. 15, str. 92. 
ovršnost. Nije je ovlašten preispitivati čak niti onda kada je ,kompromitirana ozbiljnom povredom temeljnih ljudskih prava“. ${ }^{106}$

Ipak, u odlukama oba suda u vezi s primjenom Uredbe Dublin II, odnosno zajedničkog europskog sustava azila, nazire se ponešto drugačiji pristup. U predmetu M.S.S. ${ }^{107}$ ESLJP je potvrdio već ranije izraženi stav (u predmetu Bosphorus), ${ }^{108}$ da države ugovornice Europske konvencije o temeljnim ljudskim pravima imaju pravo dio svoje suverenosti prenijeti na međunarodne organizacije, pod uvjetom da iste pružaju takvu zaštitu ljudskih prava koja se može smatrati jednakovrijednom onoj koju pruža konvencijski sustav. Time je jasno dao do znanja da smatra kako je takva zaštita u Europskoj uniji osigurana. ${ }^{109}$ Međutim, u slučajevima koji izlaze izvan okvira objektivno određenih međunarodnih obveza, dakle u slučajevima koji su prepušteni diskreciji država ugovornica, ${ }^{110}$ država ugovornica obvezna je ostvarivati svoju diskreciju na način koji vodi rezultatu kompatibilnom sa zaštitom temeljnih ljudskih prava. Odgovornost za povredu prava zaštićenih Konvencijom u tom slučaju isključiva je odgovornost te države. ${ }^{111}$ Za razliku od Suda za ljudska prava, Sud EU u predmetu N.S. v Secretary of State, ${ }^{112}$ zauzeo je nešto drugačiji stav. ${ }^{113}$ U slučajevima u kojima pravosudna suradnja rezultira povredom ljudskih prava uslijed sistemskih grešaka (systemic deficiences) u pravosudnom sustavu države članice koja je primarno odgovorna, druge države članice oslobođene su obveze suradnje.

Iako se prima faciae može govoriti o nedosljednosti samog Suda EU, te o neusklađenosti prakse obaju sudova, valja imati na umu dvije stvari. Prvo, da je pravosudna suradnja u privatnopravnim predmetima ustrojena na način da nacionalnim tijelima ne ostavlja prostora za diskreciju, za razliku od pravosudne suradnje u okviru zajedničkog europskog sustava azila. Drugo, st. 3. čl. 52. Povelje

$106, \ldots$ questions concerning the lawfulness of the judgment ... and in particular the question whether the necessary conditions enabling the court with jurisdiction to hand down that judgment are satisfied, must be raised before the courts of the Member State of origin, in accordance with the rules of its legal system" (par. 51). ,it is solely for the national courts of the Member State of origin to examine the lawfulness of that judgment with reference to the requirements imposed, in particular, by Article 24 of the Charter of Fundamental Rights and Article 42 of Regulation No 2201/2003“ (par. 69).

107 Vidi: ESLJP, predmet br. 30696/09 M.S.S. v. Belgium and Greece, od 21. siječnja 2011.

108 Vidi: ESLJP, predmet br. 45036/98 Bosphorus Hava Yollar $\square$ Turizm ve Ticaret Anonim Şirketi v. Ireland, od 30. lipnja 2005.

109 Više o tome vidi u: Novak, S.: ,Autonomija pravnog poretka Europske unije u postupku pristupanja Europskoj konvenciji za zaštitu ljudskih prava i temeljnih sloboda“, Zagrebačka pravna revija, Vol. 4, No. 1, 2015., str. 44 i 45.

110 Kao što je slučaj sa st. 2. čl. 3. Uredbe Dublin II.

111 Paris, M.-L.: „Paving the Way: Adjustment of Systems and Mutual Influences between the European Court of Human Rights and European Union Law before Accession“, Irish Jurist, Vol. 51, 2014., str. 62 .

112 Joined cases C-411/10 N.S. v Secretary of State for the Home Department and C-493/10 M.E. and Others Refugee Applications Commissioner and Minister for Justice, Equality and Law Reform [2011.] ECR I-13905.

113 Vosilyute, L.: The ECtHR and the ECJ Overlapping Jurisdiction on Common EU Asylum Policy Issues: Whatmatters?,dostupno na: https://www.academia.edu/2706355/ECtHR_and_ECJ_Overlapping Jurisdiction_on_Common_EU_Asylum_Policy_Issues_What_Matters. 
EU o temeljnim pravima Sudu EU dano je ovlaštenje da „pruži širu zaštitu“ od one garantirane Konvencijom. Taj „,nerješivi paradoks“ (an unsolved paradox), kako ga često nazivaju, predmet je brojnih kritika, osobito iz pozicije skeptika koji ne vjeruju u istinsku želju Unije u promoviranju ljudskih prava već to smatraju paravanom za jačanje prava EU. Ipak, isti stavak navodi i sljedeće: „, u mjeri u kojoj Povelja sadrži prava koja odgovaraju pravima zajamčenima Konvencijom za zaštitu ljudskih prava i temeljnih sloboda, značenje i opseg primjene tih prava jednaki su onima iz spomenute Konvencije“. Istodobno, praksa bilježi sve veći broj odluka u kojima se sudovi međusobno referiraju. Time je omogućen usporedni razvoj prakse suda EU i ESLJP-a s ciljem jačanja jednoobraznog europskog sustava ljudskih prava i temeljnih sloboda, utemeljenog na Europskoj konvenciji o ljudskim pravima i temeljnim slobodama i Povelji EU o temeljnim pravima.

\section{AKTUALNA DEBATA I BUDUĆI IZAZOVI}

Iz svega navedenoga očigledno proizlazi da u pozadini uzajamnog priznanja, u većoj ili manjoj mjeri, stoji načelo uzajamnog povjerenja. Praksa Suda EU nedvojbeno pokazuje da se u području slobode, sigurnosti i pravde u odnosima među državama članicama uzajamno povjerenje i poštovanje temeljnih (materijalnih i procesnih) prava podrazumijevaju. Takav sistemski pristup uzajamnom povjerenju, de facto „slijepo“ povjerenje (blind trust), temelji se na pretpostavci da su sve države članice sposobne osigurati učinkovitu zaštitu temeljnih prava na (apstraktnoj) institucionalnoj razini. ${ }^{114}$ Ipak, nameće se pitanje je li to baš tako i postoji li konsenzus u tom smislu?

Primjerice, prilikom revizije Uredbe Brisel I Komisija je, ohrabrena studijom koju je provelo Sveučilište u Heidelbergu, ${ }^{115}$ a koja je pokazala da je broj predmeta u kojima je uspješno aktivirana klauzula supstancijalnog javnog poretka gotovo zanemariv, predložila potpuno ukidanje razloga za priznanje i ovrhu (automatsko priznanje i ovrhu) uz zadržavanje limitirane kontrole u državi članici porijekla odluke. Pokazalo se da države članice nisu bile spremne za takav iskorak.

Legitimnost takve odluke mogla bi se pravdati na različite načine. ${ }^{116}$ Jedan, vrijedan promišljanja, ističe Dickinson te navodi da se uzajamno povjerenje može

114 Mitsilegas, op. cit., bilj. 14, str. 353-355.

115 Hess, B./Pfeiffer, T.: Interpretation of the Public Policy Exception as referred to in EU instruments of Private International and Procedural Law, EU Parliament, 2011., dostupno na: www.europarl.europa. eu/studies.

116 Primjerice, argumentom da se ne može svaki odnos tretirati kao „robu“ (commercial goods), kao što su argumentirali Jayme i Kohler u kontekstu pravosudne suradnje u obiteljskim predmetima. Jayme, E./Kohler, C.: Europäisches Kollisionsrecht 2001: Anerkennungsprinzip statt IPR?, Praxis des internationalen Privat- und Verfahrensrecht, 2001., str. 501; Kohler, C.: „Status als Ware: Bemerkungen zur europäischen Verordnung über das internationale Verfahrensrecht in Ehesachen“, u: Mansel. H.-P. (ur.): Vergemeinschaftung des Kollisionsrechts - Vorträge und Reden anlässlich der Feier des fünfzigjährigen bestehens des Instituts für internationales und ausländisches privatrecht der Universität zu Köln, Cologne, 2001., str. 41 . 
vezivati isključivo uz primjenu europskog prava, a ne uz primjenu nacionalnog prava. ${ }^{117}$ Naime, pravo je i obveza svake države članice štititi vlastiti javni poredak i u tom smislu ima pravo zadržati zapreke koje smatra neophodnima za ostvarenje tog cilja. Argument da su sve države članice EU vezane Poveljom EU o temeljnim ljudskim pravima, ${ }^{118}$ oslabljuje opsežna sudska praksa Europskog suda za ljudska prava, ${ }^{119}$ te Suda EU, ${ }^{120}$ koja zorno pokazuje da se implementacija prava na pravično (pošteno) suđenje uvelike razlikuje od države do države. Pored toga, i sam Sud za ljudska prava potvrdio je da i uzajamno povjerenje ima svoje granice, ${ }^{121}$ određene temeljnim pravima.

Očigledno, uzajamno priznanje utemeljeno na „slijepom“ povjerenju traži dodatno promišljanje. Argument, uklanjanja zapreka“ radi omogućavanja slobodnog kretanja odluka postaje upitan u slučajevima gdje je došlo do povrede temeljnih prava koja nije korigirana u državi porijekla odluke. ${ }^{122}$ Baš naprotiv, u takvim slučajevima automatsko priznanje omogućilo bi slobodno kretanje i onih odluka koje ne bi trebale biti priznate i ovršene niti u jednoj državi članici. Stoga bi, imajući u vidu i lokalne prilike, trebalo dodatno razmotriti je li automatsko priznanje, utemeljeno na ,slijepom“ povjerenju, najprikladniji regulatorni mehanizam priznanja i ovrhe u području slobode, sigurnosti i pravde. ${ }^{123}$

\section{ZAKLJUČAK}

Još od 90-ih godina prošlog stoljeća, načelo uzajamnog povjerenja provlači se kao nit vodilja kroz cijeli proces prilagodbe prava, s ciljem stvaranja uvjeta za slobodno kretanje odluka. Odnosi se na povjerenje koje bi države članice EU trebale imati u odnosu na pravne sustave i sudove drugih država članica. Iako se ni u UEU-u niti u UFEU-u uzajamno povjerenje nigdje eksplicitno ne spominje, ${ }^{124}$ Europska Komisija ga nedvojbeno priznaje kao ključnu komponentu u uspostavljanju

117 Dickinson, A.: „Free Movement of Judgments in the EU: Knock Down the Walls but Mind the Ceiling", u: Lein. E.: The Brussels I review Proposal Uncovered, British Institute for International and Comparative Law, London, 2012., str. 135.

118 Povelja Europske unije o temeljnim pravima, S1. 1. EU C 301/3, od 12. XII. 2007.

119 Vidi: ESLJP, predmet br. 45036/98 Bosphorus Hava Yollar $\square$ Turizm ve Ticaret Anonim Şirketi v. Ireland, od 30. lipnja 2005.; predmet br. 30882/96 Pellegrini v. Itally, od 20. srpnja 2001.

120 Vidi: CJEU, Case C-7/98 Dieter Krombach v. André Bamberski [2001.] ECR I-1935; Case-394/7 Marco Gambazzi v. DaimlerChrysler Canada Inc. and CIBC Mellon Trust Company [2009.] ECR I-2563.

121 Vidi: ESLJP, predmet br. 30696/09 M.S.S. v. Belgium and Greece, od 21. siječnja 2011. Vidi i: Raulus, H.: „Fundamental Rights in the Area of Freedom, Security and Justice“, u: Wolff, S./Goudappel, F.A.N.J./de Zwaan, J. (ur.): Security and Justice after Lisbon and Stockholm, Asser Press, The Hague, 2011., str. 233.

122 Storskrubb, E.: Ordre Public in EU Civil Justice - Lessons from Arbitration?, Festskrift till Gustaf Möller, Juridiska Föreningen i Finland, 2011.

${ }^{123}$ Kramer, X.E.: Procedure Matters, Construction and Deconstructivisam in European Civil Procedure, Eleven International Publishing, The Hague, 2013., str. 27.

${ }^{124}$ Za razliku od čl. I-42(1)(b) propalog Ustava za Europu, gdje je izrijekom navedeno da će Unija ustrojiti područje slobode, sigurnosti i pravde, utemeljeno na ,uzajamnom povjerenju“ između nadležnih 
područja slobode, sigurnosti i pravde. ${ }^{125}$ I čini se da, usprkos izazovima koje pred uzajamno povjerenje stavljaju stalna proširenja, te usprkos limitiranom uspjehu proceduralne harmonizacije, pravo EU i dalje nastavlja svoju evoluciju u smjeru daljnjeg olakšavanja priznanja i ovrhe.

Ipak, ne treba zaboraviti niti izazove koji s time dolaze. Iz perspektive države, normativni sustav uzajamnog povjerenja u građanskim predmetima prilično je zahtjevan. Snaga uvjerljivosti uzajamnog povjerenja je limitirana, a uzajamno povjerenje kao neoboriva presumpcija ne funkcionira, ${ }^{126}$ osobito izvan granica koje je dosegao sam sustav. Mješavina različitih režima priznanja i ovrhe, u kombinaciji s neusklađenom sudskom praksom, rezultirala je fragmentiranim i nekoherentnim europskim procesnim pravom te zahtijeva temeljito preispitivanje o najprikladnijem režimu priznanja i ovrhe na području EU.

Iz perspektive pojedinca, istraživanja pokazuju da većina europskih državljana vjeruje da u pogledu kvalitete, učinkovitosti i nezavisnosti postoje ogromne razlike među pravosudnim sustavima država članica. ${ }^{127}$ Jednako tako, većina građana nema povjerenja niti u vlastiti pravosudni sustav. ${ }^{128}$ Ipak, to ne sprečava Uniju da pravosudnu suradnju u građanskim predmetima, utemeljenu na načelu uzajamnog priznanja, i dalje opravdava pozivanjem na uzajamno povjerenje.

Budući da je upravo pravosudna politika EU percipirana kao jedan od ključnih faktora integracije EU, kojim je moguće osigurati u potpunosti funkcionalno zajedničko europsko područje pravde, ${ }^{129}$ i EU i države članice trebale bi biti proaktivne u jačanju uzajamnog povjerenja među nacionalnim tijelima, osobito, nacionalnim sudovima. To, među ostalim, uključuje i olakšanje primjene načela uzajamnog priznanja usvajanjem zakonodavstva koje potiče uzajamno povjerenje. Načelo uzajamnog priznanja dragocjeno je kao radna premisa, ali nikako ne bi trebalo stajati na putu otvorene diskusije o tome što se događa ili ne događa u državama članicama. ${ }^{130} \mathrm{U}$ svakom slučaju, uzajamno povjerenje ne bi se smjelo

tijela država članica, a osobito na uzajamnom priznanju odluka u sudskim i izvansudskim predmetima među državama članicama.

125 Vidi: Komunikacija Komisije Europskom parlamentu, Vijeću, Europskom gospodarskom i socijalnom odboru i Odboru regija, Agenda EU za pravosuđe - Jačanje povjerenja, mobilnosti i rasta unutar Unije, COM (2014.) 144 final, Strasburg, 1. III. 2014. i Kaufhold, A.-K.: „Wirksamkeitsbedingungen und Rechtsprinzip der justiziellen Zusammenarbeit in Raum der Freiheit, der Sicherheit und des Rechts“, Zeitschrift für Europarecht, 2012., str. 408 i 411. 120.

${ }^{126}$ Knauer, N. J.: „Legal Fictions and Juristic Truth“, St. Thomas Law Review, Vol. 23, 2010., str. 70-

${ }_{127}$ Primjerice: European Commission, Flash Eurobarometar 385, „Justice in the EU“, Report conducted by TNS Political \& Social at the request of the European Commission, Directorate-General for Justice (DG JUST); Survey co-ordinated by the European Commission, Directorate-General for Communication (DG COMM), November 2013.

${ }^{128}$ European Commission, „The 2014 EU Justice Scoreboard: Towards More Effective Justice Systems in the EU“, Press Release, IP/14-273, od 17. ožujka 2014. Dostupno na http://europa.eu/rapid/ press-release_IP-14-273_en.htm.

${ }^{129}$ Komunikacija Komisije, bilj. 125, str. 10.

${ }^{130}$ Kramer, op. cit., bilj. 123, str. 27. 
zamijeniti „slijepim povjerenjem“. ${ }^{131}$ Zaštita temeljnih ljudskih prava trebala bi biti imperativ, ne samo u slučaju sistemskih grešaka, nego i u individualnim slučajevima. Drugim riječima, sloboda kretanja odluka ne bi trebala biti apsolutna, a uzajamno povjerenje i različitosti u nacionalnim sustavima ne bi trebale ići na uštrb temeljnih ljudskih prava.

\section{RECOGNITION AND ENFORCEMENT IN THE EU - MUTUAL TRUST AND THE PROTECTION OF FUNDAMENTAL FREEDOMS}

In the area of freedom, security and justice, mutual trust is closely related to mutual recognition. Mutual recognition enables the decision reached in one member state to be recognised and enforced in another member state as if it were a domestic decision. There is no mutual recognition without mutual trust. There is no mutual trust without protection of fundamental human rights. Even though in primary EU law it is not expressedly stated, mutual trust is explicitly stated as the intersection of numerous acts of secondary EU law. Unfortunately, the European legislator has not made an effort to clarify the possible meanings and role of this syntagma. Therefore, in this paper we refer to the development of the idea of mutual trust, then to the role of mutual trust as foundations for recognition and enforcement in the context of the internal market and the area of freedom, security and justice and finally, in EU court's and European Court of Human Rights' practice.

Key words: European Union, recognition and enforcement, mutual trust, fundamental human rights.

${ }^{131}$ Lenaerts, op. cit., bilj. 9., str. 29. 